Candidate susceptibility variants in angioimmunoblastic T-cell lymphoma

\author{
Donner, likki
}

2019-01

Donner , I, Katainen , R , Kaasinen , E , Aavikko , M , Sipilä , L J , Pukkala , E \& Aaltonen , L A 2019 , ' Candidate susceptibility variants in angioimmunoblastic T-cell lymphoma ' , Familial Cancer , vol. 18 , no. 1 , pp. 113-119 . https://doi.org/10.1007/s10689-018-0099-x

http://hdl.handle.net/10138/298283

https://doi.org/10.1007/s10689-018-0099-x

publishedVersion

Downloaded from Helda, University of Helsinki institutional repository.

This is an electronic reprint of the original article.

This reprint may differ from the original in pagination and typographic detail.

Please cite the original version. 


\title{
Candidate susceptibility variants in angioimmunoblastic T-cell lymphoma
}

\author{
likki Donner ${ }^{1,2} \cdot$ Riku Katainen $^{1,2} \cdot$ Eevi Kaasinen ${ }^{1,2,3} \cdot$ Mervi Aavikko $^{1,2} \cdot$ Lauri J. Sipilä $^{1,2} \cdot$ Eero Pukkala $^{4,5}$. \\ Lauri A. Aaltonen ${ }^{1,2}$
}

Published online: 10 August 2018

(c) Springer Nature B.V. 2018

\begin{abstract}
Angioimmunoblastic T-cell lymphoma (AITL) is a subtype of peripheral T-cell lymphoma with a poor prognosis: the 5-year survival rate is approximately $30 \%$. Somatic driver mutations have been found in TET2, IDH2, DNMT3A, RHOA, FYN, PLCG1, and CD28, whereas germline susceptibility to AITL has to our knowledge not been studied. The homogenous Finnish population is well suited for studies on genetic predisposition. Here, we performed an exome-wide rare variant analysis in 23 AITL patients. No germline mutations were found in the driver genes, implying that they are not frequently involved in genetic AITL predisposition. Potentially pathogenic variants present in at least two patients and showing significant $(\mathrm{p}<0.01)$ enrichment in our sample set were found in ten genes: POLK, PRKCB, ZNF676, PRRC2B, PCDHGB6, GNL3L, TTC36, OTOG, OSGEPL1, and RASSF9. The most significantly enriched variants, causing p.Lys469Ter in a splice variant of $P O L K$ and p.Pro588His in $P R K C B$, are intriguing candidates as Polk deficient mice display a spontaneous mutator phenotype, whereas $P R K C B$ was recently shown to be somatically mutated in $33 \%$ of another peripheral T-cell lymphoma, adult T-cell lymphoma. If validated, our findings would provide new insight into the pathogenesis of AITL, as well as tools for early detection in susceptible individuals.
\end{abstract}

\section{Introduction}

Angioimmunoblastic T-cell lymphoma (AITL) is a subtype of peripheral T-cell lymphoma (PTCL). It accounts for approximately $1-2 \%$ of malignant lymphomas and nearly $20 \%$ of PTCL [1]. AITL typically afflicts individuals of advanced age (median age at diagnosis 65) and has a poor

Lauri A. Aaltonen

lauri.aaltonen@helsinki.fi

1 Department of Medical and Clinical Genetics, Medicum, Faculty of Medicine, University of Helsinki, Helsinki, Finland

2 Genome-Scale Biology Research Program, Research Programs Unit, Faculty of Medicine, University of Helsinki, Helsinki, Finland

3 Division of Functional Genomics and Systems Biology, Department of Medical Biochemistry and Biophysics, Karolinska Institutet, Stockholm, Sweden

4 Finnish Cancer Registry, Institute for Statistical and Epidemiological Cancer Research, Helsinki, Finland

5 Faculty of Social Sciences, University of Tampere, Tampere, Finland prognosis with a 5-year survival rate of approximately $30 \%$. The malignant cells originate from $\mathrm{T}$ follicular helper (TFH) cells and preserve the major functions of this cell type. In recent years, a number of nodal PTCLs previously classified as PTCL, not otherwise specified (NOS), have been found to have TFH-cell features. Follicular T-cell lymphoma, for example, shows genetic overlap with AITL, which has led to these two being unified under the heading "AITL and other nodal lymphomas of TFH cell origin", in the recently revised WHO Classification of Tumours of the Haematopoietic and Lymphoid Tissues [2].

The majority of the tumor cells in AITL can be found in lymph nodes, liver, spleen, skin, and bone marrow. The malignancy is characterized by an extensive surrounding tumor microenvironment populated by various reactive cell types such as T- and B-cells, B immunoblasts, plasma cells, eosinophils and macrophages. Tumor cells are often in the minority, comprising as little as $10 \%$ of an AITL lesion [3]. Epstein-Barr virus (EBV) is a potentially oncogenic virus associated with both lymphoproliferative disorders and solid tumors. It has been linked in particular to endemic Burkitt's lymphoma, a pediatric cancer in which EBV coinfection with malaria in early life is a major contributing factor [4]. 
The majority of AITL cases are also positive for EBV, however, it is rarely the malignant $\mathrm{T}$ cells that are infected, but instead the reactive $\mathrm{B}$ cells $[5,6]$.

Recurrent somatic mutations in the epigenetic regulators TET2 (47-76\% of cases), IDH2 (20-45\% of cases) and DNMT3A (33\% of cases) have been detected in AITL, indicating that epigenetic aberrations are a major driver of AITL lymphomagenesis [7-10]. Mutations in $I D H 2$ are restricted to $\operatorname{Arg} 172$, and this mutation occurs almost exclusively in AITL. Mutations in TET2, IDH2 and DNMT3A have been shown to co-occur in AITL, whereas they are mutually exclusive in acute myeloid leukemia. It is noteworthy that the DNMT3A and TET2 mutations found in AITL and other hematopoietic malignancies are commonly detected in a clonal subpopulation of blood cells derived from a single progenitor with a growth advantage - a phenomenon termed clonal hematopoiesis - in elderly individuals. Due to a high prevalence of clonal hematopoiesis in healthy elderly individuals, additional genetic or epigenetic changes are likely required to drive lymphomagenesis [11].

Nearly $70 \%$ of AITL cases have the specific p.Gly 17 Val mutation in the small GTPase RHOA [12, 13]. Alterations in diverse T-cell receptor signaling genes (PLCG1, CD28, PIK3 elements, GTF2I, CTNNB1) were found in approximately half the AITL cases in a study by Vallois et al. 2016 [14]. The same study confirmed a high (60\%) prevalence of p.Gly17Val substitutions in RHOA in AITL, and also reported a novel substitution p.Lys18Asn in three patients. Recurring mutations in CD28 in AITL have been described earlier by Rohr et al. 2016 [15].

To our knowledge, genetic predisposition to AITL has never been studied. In this study we sequenced the germline exomes of 23 AITL patients. We looked for shared rare variants significantly enriched in our sample set when compared to population specific controls, and for germline mutations in genes known to be somatically mutated in AITL.

\section{Materials and methods}

\section{Ethics statement}

This study was approved by the National Supervisory Authority for Welfare and Health (Valvira; 1423/06.01.03.01/2012), National Institute for Health and Welfare (THL; 151/5.05.00/2017), and the ethics committee of the Hospital District of Helsinki and Uusimaa (HUS; 408/13/03/03/09).

\section{Patients and samples}

We utilized the Finnish Cancer Registry (FCR), which was established in 1952 and harbors data on all cancer cases diagnosed in Finland since 1953 [16], to find patients with AITL. Altogether 136 patients had been diagnosed with this malignancy between 1953 and 2015. Non-malignant formalin-fixed paraffin-embedded (FFPE) tissue material was collected from 43 patients. In many cases tissue material was too scarce to obtain adequate amounts of DNA for successful sample preparation. In the end, the exomes of 23 patients (15 male, 8 female) were successfully sequenced. Median age at diagnosis of these patients was 57 years (range 30-84). Sex and age at diagnosis of the patients are listed in Table 1.

During the revision process of this manuscript, we found that one of the patients, AITL42, had mistakenly been listed as having an AITL diagnosis in the FCR. The correct diagnosis was PTCL-NOS, which at the time included also TFH phenotype malignancies. Based on patient records the exact phenotype of the patient's malignancy was never determined, nor was AITL excluded. Whether the malignant cells had TFH features had not been determined. Because of genetic overlap between these two lymphomas, we decided to retain her data in the study.

\section{Exome sequencing}

Genomic DNA was extracted from archival FFPE tissue samples with the phenol-chloroform method and prepared for exome sequencing with the KAPA Hyper Prep Kit (Kapa Biosystems Inc., Wilmington, MA) and SeqCap EZ System (Roche Nimblegen Inc., Madison, WI). We used 300-1000 ng of DNA sheared to an average size of 200-300 bp with the Covaris S220 Focused-ultrasonicator (Covaris Inc., Woburn, MA). For target enrichment we used the $96 \mathrm{Mb}$ SeqCap EZ Exome + UTR (Roche Nimblegen Inc.) kit. Paired-end sequencing was performed with Illumina HiSeq 4000 (Illumina, San Diego, CA) at Karolinska High Throughput Center. Average coverage across all samples was 38 reads, and $87 \%$ of targeted areas were covered by ten or more reads.

\section{Data analysis}

For a brief description of the pipeline used on the raw sequencing data, please refer to Donner et al. 2017 [17].

Annotation, comparative variant analysis, controlling, and variant visualization were performed with BasePlayer (https ://doi.org/10.1101/126482). Gene annotation was based on Ensembl GRCh37 release 84 . Minimum coverage was set at ten reads and minimum allelic fraction at $30 \%$. We used two different variant control data sets for MAF filtering: gnomAD (full set) [18] and the gnomAD Finnish subset $(n=12,897)$. We looked for rare, likely pathogenic variants in genes known to be recurrently somatically mutated in AITL: TET2, DNMT3A, IDH2, CD28, FYN, PLCG1, and RHOA. The variants were required to have a $\mathrm{MAF}<0.01$ 
Table 1 Sex, age at diagnosis, EBV status, and outcome of the patients included in this study

\begin{tabular}{lllll}
\hline ID & Sex & $\begin{array}{l}\text { Age at diag- } \\
\text { nosis }\end{array}$ & EBV status & Survival in months \\
\hline AITL4 & F & 44 & + & \\
AITL7 & M & 57 & + & 50 \\
AITL8 & M & 31 & + & 23 \\
AITL10 & M & 65 & - & 41 \\
AITL11 & M & 52 & - & Remission (71 months since diagnosis) \\
AITL12 & M & 52 & N/A & 28 \\
AITL13 & F & 65 & N/A & 56 \\
AITL14 & F & 69 & + & 83 \\
AITL15 & M & 71 & + & Remission (85 months since diagnosis) \\
AITL17 & F & 82 & N/A & 10 \\
AITL18 & M & 84 & - & Alive (77 months since diagnosis) \\
AITL22 & M & 45 & + & 20 (death not cancer related) \\
AITL24 & M & 49 & N/A & 44 \\
AITL25 & F & 70 & - & 32 \\
AITL30 & M & 55 & + & 15 \\
AITL31 & M & 55 & N/A & 21 (death not cancer related) \\
AITL33 & M & 57 & + & 9 \\
AITL35 & M & 58 & + & 89 \\
AITL36 & F & 58 & N/A & Remission (124 months since diagnosis) \\
AITL39 & M & 42 & - & 41 (death not cancer related) \\
AITL42 & F & 55 & - & 25 \\
AITL43 & M & 30 & 71 & Alive (49 months since diagnosis) \\
AITL45 & F & + & 12 \\
\hline & & & Remission (44 months since diagnosis) \\
\hline
\end{tabular}

in the two gnomAD sets used. Variants in other genes were required to be present in at least two patients, have a MAF of $<0.01$ in the two control sets, and to be significantly $(\mathrm{p}<0.01)$ enriched in our sample set as determined by Fisher's exact test. Odds ratios and confidence intervals were calculated using conditional Maximum Likelihood Estimate. Effects of missense variants as well as in-frame deletions and insertions were predicted with Provean, SIFT, and PolyPhen-2 [19-21]. Variants were required to be predicted deleterious using the available algorithms' default threshold values in order to pass filtering.

\section{Validation by Sanger sequencing}

Candidate variants were validated by Sanger sequencing of DNA extracted from FFPE blocks with the GeneRead DNA FFPE Kit (Qiagen). Primers were designed with Primer3web version 4.0.0 (http://primer3.ut.ee/) and capillary sequencing was performed at the Institute for Molecular Medicine Finland (FIMM) using the BigDye v.3.1 sequencing reaction and $\mathrm{ABI} 3730 \mathrm{xl}$ DNA Analyzer electrophoresis (Applied Biosystems, Foster City, CA). Each reaction was performed in three replicates in order to exclude monoallelic amplification.

\section{Results}

We were not able to detect any rare, likely pathogenic variants in genes frequently somatically mutated in AITL: TET2, DNMT3A, IDH2, CD28, PLCG1, FYN, and RHOA. Potentially pathogenic variants present in at least two patients and showing significant enrichment in our sample set were found in ten genes: POLK, PRKCB, ZNF676, PRRC2B, PCDHGB6, GNL3L, TTC36, OTOG, OSGEPL1, and RASSF9. The variants are listed in Table 2 in descending order of their odds ratio. Variants found in PRKCB and OSGEPL1 were both shared by three patients, and variants in the other eight genes were shared by two.

\section{Discussion}

The Finnish population has reduced genetic heterogeneity and publicly available population control genotypes are plentiful, which makes this population well suited for studies on genetic predisposition. Here, we set out to study genetic susceptibility to AITL.

Genes known to be somatically mutated in AITLs, listed in Swerdlow et al. [2], did not harbor any rare potentially pathogenic germline point mutations or INDELs, 


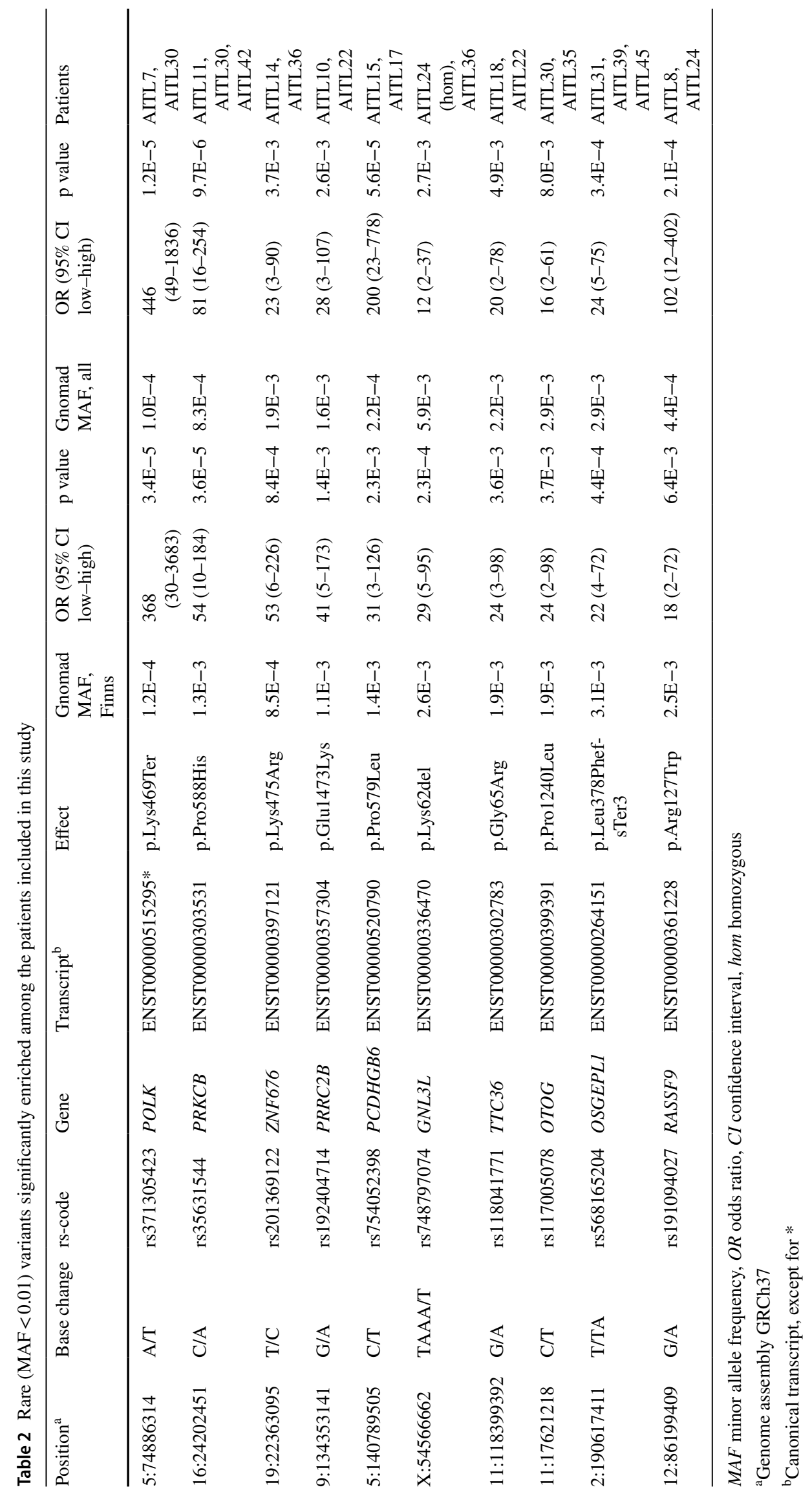


implying that they are infrequently involved in susceptibility to the disease. However, larger structural variation could not be looked into due to the limitations of exome data. We also looked for enrichment of rare potentially pathogenic variants throughout the exome. The most significantly enriched variant in our sample set was a nonsense change p.Lys469Ter in a non-canonical splice variant (ENST00000515295) of POLK, shared by two patients. The isoform differs from the canonical sequence at amino acids 453-472, and lacks the canonical amino acids 473-870. Although the structure and function of the main isoform of POLK are known, the role of isoform 2, which is affected in our patients, is unknown. POLK is one of four Y-family bypass polymerases that can replicate through damaged DNA. High-fidelity DNA polymerases are usually blocked by bulky DNA lesions, but can be replaced by one or more bypass polymerases for local translesion synthesis (TLS). POLK is involved in errorfree TLS opposite $N^{2}$-guanyl DNA adducts induced by carcinogens such as polycyclic aromatic hydrocarbons [22]. While TLS by the appropriate bypass polymerase is largely error-free, its absence forces other similar enzymes to take its place to rescue cells from the lethal consequences of arrested DNA replication. However, these enzymes are not optimal, and often generate an increased mutational burden, as is the case if the appropriate enzyme is functionally impaired. Accordingly, mice defective for the Polk gene (Polk-/-) have a spontaneous mutator phenotype [23]. It is thus conceivable that certain germline POLK variants might alter the functionality of the enzyme and modify individual risk of mutation and cancer in the presence of carcinogens. While $P O L K$ is an intriguing candidate gene, the variant shared by our patients truncates the isoform just three amino acids prematurely. Neither somatic nor germline mutations in POLK have to our knowledge been reported in AITL or other T-cell lymphomas.

The second most significantly enriched variant, present in three patients, was a missense substitution p.Pro588His in the catalytic kinase domain (amino acids 342-600) of a protein kinase $\mathrm{C}(\mathrm{PKC})$ family member $P R K C B$. Chronic lymphocytic leukemia cells have been shown to overexpress PRKCB [24]. Also, more recent research on adult T-cell lymphoma (ATL) found the gene to be somatically mutated in $33 \%$ of cases [25]. Ninety-three percent of these mutations were confined to highly conserved regions within the catalytic domain, suggesting gain-of-function and thus an oncogenic nature in ATL. The PKC family has historically been considered to consist of oncoproteins. Recently, however, they have been suggested to have a tumor suppressive rather than oncogenic role [26]. One of the patients harboring the p.Pro588His variant was found to have a PTCL-NOS rather than an AITL diagnosis during the revision process of this manuscript.
The variant with the third highest odd ratio was a missense variant causing p.Lys475Arg in ZNF676. Polymorphisms in ZNF676 have been associated with leukocyte telomere length variation in two separate studies [27, 28]. The function of the gene is unknown.

Two genes, GNL3L and RASSF9, with predicted pathogenic germline variants in two AITL patients each, had known functions related to proliferation. GNL3L is a putative nucleolar GTPase required for cell proliferation and normal processing of ribosomal pre-rRNA [29]. It increases homodimerization, protein stability, and telomeric association of TRF1, a protein that negatively controls telomeric length by denying telomerase access to the telomeres [30]. The TRF1-stabilizing function of GNL3L causes a mitotic increase in TRF1, and promotes the transition from metaphase to anaphase during mitosis. GNL3L has also been suggested to participate in maintaining the function of so called tumor initiating cells [31], and in the regulation of cell proliferation during tumorigenesis by modulation of NF- $\mathrm{KB}$ signaling [32]. RASSF9 is associated with endosomes and is linked to vesicle trafficking [33]. It binds the Ras family proteins N-Ras, K-Ras, and R-Ras [34]. RASSF9 null mice exhibit severe growth retardation and short lifespan [35]. RASSF9 is predominantly expressed in epidermal keratinocytes of skin, and null mice also display a change in epithelial organization of skin, with increased proliferation and aberrant differentiation.

OTOG, with shared variants in two AITL patients, encodes otogelin, a glycoprotein specific to acellular membranes of the inner ear [36]. Mutations in the gene have been found to cause autosomal recessive non-syndromic hearing impairment [37, 38]. Based on this function, it appears unlikely that the variant reported here has a role in AITL lymphomagenesis. The function of the remaining genes with shared variants in our sample set: PRRC2B, PCDHGB6, TTC36, and $O S G E P L 1$, have to date been poorly described.

Of the patients, 16 had been tested for EBV infection. Of these ten were found to be positive, which is a somewhat low fraction compared to previous reports [6]. Considering the role that EBV infection together with malaria plays in Burkitt's lymphoma, it is intriguing to speculate that infection together with a specific genotype could constitute a risk factor for AITL. However, rather than contributing to the disease itself, it is possible that EBV is reactivated due to AITL induced immunodeficiency [6]. Another possibility is that EBV infection plays an important role in the development of the extensive microenvironment in AITL. To robustly link EBV infection causally to AITL pathology requires future studies with large sample sets.

Based on known function and previous studies, the most intriguing variants described here are the ones found in $P O L K$ and $P R K C B$. As a limitation of the work, we only looked at rare variants and AITL susceptibility could also 
emerge through more common variants that would have been missed by our screen. While emanating from a populationbased source our final sample set was relatively small, and incidental enrichment of the variants cannot be excluded. If validated in independent sample sets, the findings would provide important new insight into the molecular pathogenesis of AITL, as well as tools for early detection of the condition in susceptible individuals.

Acknowledgements This work was supported by the Academy of Finland, Finnish Center of Excellence Program 2012-2017 [Grant Number 250345]. We wish to thank Heikki Metsola, Sini Nieminen, Alison Ollikainen, Marjo Rajalaakso, Sirpa Soisalo, Inga-Lill Svedberg, and Iina Vuoristo for their indispensable assistance.

\section{References}

1. Federico M, Rudiger T, Bellei M, Nathwani BN, Luminari S, Coiffier B, Harris NL, Jaffe ES, Pileri SA, Savage KJ, Weisenburger DD, Armitage JO, Mounier N, Vose JM (2013) Clinicopathologic characteristics of angioimmunoblastic T-cell lymphoma: analysis of the international peripheral T-cell lymphoma project. J Clin Oncol 31:240-246

2. Swerdlow SH, Campo E, Harris NL, Jaffe ES, Pileri SA, Stein H, Thiele J (2017) WHO classification of tumours of haematopoietic and lymphoid tissues. IARC, Lyon

3. de Leval L, Rickman DS, Thielen C, Reynies AD, Huang YL, Delsol G, Lamant L, Leroy K, Brière J, Molina T, Berger F, Gisselbrecht C, Xerri L, Gaulard P (2007) The gene expression profile of nodal peripheral T-cell lymphoma demonstrates a molecular link between angioimmunoblastic T-cell lymphoma (AITL) and follicular helper T (TFH) cells. Blood 109:4952-4963

4. Rochford R, Moormann AM (2015) Burkitt's lymphoma. In: Münz C (ed) Epstein Barr virus, vol 1. Springer, Cham

5. Zhou Y, Attygalle AD, Chuang SS, Diss T, Ye H, Liu H, Hamoudi RA, Munson P, Bacon CM, Dogan A, Du MQ (2007) Angioimmunoblastic T-cell lymphoma: histological progression associates with EBV and HHV6B viral load. Br J Haematol 138:44-53

6. Chen YP, Jones D, Chen TY, Chang KC (2014) Epstein-Barr virus present in $\mathrm{T}$ cells or B cells shows differential effects on hemophagocytic symptoms associated with outcome in T-cell lymphomas. Leuk Lymphoma 55:2038-2047

7. Lemonnier F, Couronné L, Parrens M, Jaïs JP, Travert M, Lamant L, Tournillac O, Rousset T, Fabiani B, Cairns RA, Mak T, Bastard C, Bernard OA, de Leval L, Gaulard P (2012) Recurrent TET2 mutations in peripheral T-cell lymphomas correlate with TFH-like features and adverse clinical parameters. Blood 120:1466-1469

8. Odejide O, Weigert O, Lane AA, Toscano D, Lunning MA, Kopp N, Kim S, van Bodegom D, Bolla S, Schatz JH, Teruya-Feldstein J, Hochberg E, Louissaint A, Dorfman D, Stevenson K, Rodig SJ, Piccaluga PP, Jacobsen E, Pileri SA, Harris NL, Ferrero S, Inghirami G, Horwitz SM, Weinstock DM (2014) A targeted mutational landscape of angioimmunoblastic T-cell lymphoma. Blood 123:1293-1296

9. Cairns RA, Iqbal J, Lemonnier F, Kucuk C, de Leval L, Jais JP, Parrens M, Martin A, Xerri L, Brousset P, Chan LC, Chan WC, Gaulard P, Mak TW (2012) IDH2 mutations are frequent in angioimmunoblastic T-cell lymphoma. Blood 119:1901-1903

10. Wang C, McKeithan TW, Gong Q, Zhang W, Bouska A, Rosenwald A, Gascoyne RD, Wu X, Wang J, Muhammad Z, Jiang B, Rohr J, Cannon A, Steidl C, Fu K, Li Y, Hung S, Weisenburger DD, Greiner TC, Smith L, Ott G, Rogan EG, Staudt LM,
Vose J, Iqbal J, Chan WC (2015) IDH2R172 mutations define a unique subgroup of patients with angioimmunoblastic T-cell lymphoma. Blood 126:1741-1752

11. Xie M, Lu C, Wang J, McLellan MD, Johnson KJ, Wendl MC, McMichael JF, Schmidt HK, Yellapantula V, Miller CA, Ozenberger BA, Welch JS, Link DC, Walter MJ, Mardis ER, Dipersio JF, Chen F, Wilson RK, Ley TJ, Ding L (2014) Age-related mutations associated with clonal hematopoietic expansion and malignancies. Nat Med 20:1472-1478

12. Palomero T, Couronné L, Khiabanian H, Kim MY, AmbesiImpiombato A, Perez-Garcia A, Carpenter Z, Abate F, Allegretta M, Haydu JE, Jiang X, Lossos IS, Nicolas C, Balbin M, Bastard C, Bhagat G, Piris MA, Campo E, Bernard OA, Rabadan R, Ferrando AA (2014) Recurrent mutations in epigenetic regulators, RHOA and FYN kinase in peripheral $\mathrm{T}$ cell lymphomas. Nat Genet 46:166-170

13. Sakata-Yanagimoto M, Enami T, Yoshida K, Shiraishi Y, Ishii R, Miyake Y, Muto H, Tsuyama N, Sato-Otsubo A, Okuno Y, Sakata S, Kamada Y, Nakamoto-Matsubara R, Tran NB, Izutsu K, Sato Y, Ohta Y, Furuta J, Shimizu S, Komeno T, Sato Y, Ito T, Noguchi M, Noguchi E, Sanada M, Chiba K, Tanaka H, Suzukawa K, Nanmoku T, Hasegawa Y, Nureki O, Miyano S, Nakamura N, Takeuchi K, Ogawa S, Chiba S (2014) Somatic RHOA mutation in angioimmunoblastic $\mathrm{T}$ cell lymphoma. Nat Genet 46:171-175

14. Vallois D, Dobay MP, Morin RD, Lemonnier F, Missiaglia E, Juilland M, Iwaszkiewicz J, Fataccioli V, Bisig B, Roberti A, Grewal J, Bruneau J, Fabiani B, Martin A, Bonnet C, Michielin O, Jais JP, Figeac M, Bernard OA, Delorenzi M, Haioun C, Tournilhac O, Thome M, Gascoyne RD, Gaulard P, de Leval L (2016) Activating mutations in genes related to TCR signaling in angioimmunoblastic and other follicular helper T-cell-derived lymphomas. Blood 128:1490-1502

15. Rohr J, Guo S, Huo J, Bouska A, Lachel C, Li Y, Simone PD, Zhang W, Gong Q, Wang C, Cannon A, Heavican T, Mottok A, Hung S, Rosenwald A, Gascoyne R, Fu K, Greiner TC, Weisenburger DD, Vose JM, Staudt LM, Xiao W, Borgstahl GE, Davis S, Steidl C, McKeithan T, Iqbal J, Chan WC (2016) Recurrent activating mutations of CD28 in peripheral T-cell lymphomas. Leukemia 30:1062-1070

16. Pukkala E, Engholm G, Højsgaard Schmidt LK, Storm H, Khan S, Lambe M, Pettersson D, Ólafsdóttir E, Tryggvadóttir L, Hakanen T, Malila N, Virtanen A, Johannesen TB, Larønningen S, Ursin G. 2018. Nordic Cancer Registries - an overview of their procedures and data comparability. Acta Oncol 57:440-455

17. Donner I, Katainen R, Tanskanen T, Kaasinen E, Aavikko M, Ovaska K, Artama M, Pukkala E, Aaltonen LA (2017) Candidate susceptibility variants for esophageal squamous cell carcinoma. Genes Chromosom Cancer 56:453-459

18. Lek M, Karczewski KJ, Minikel EV, Samocha KE, Banks E, Fennell T, O'Donnell-Luria AH, Ware JS, Hill AJ, Cummings BB, Tukiainen T, Birnbaum DP, Kosmicki JA, Duncan LE, Estrada K, Zhao F, Zou J, Pierce-Hoffman E, Berghout J, Cooper DN, Deflaux N, DePristo M, Do R, Flannick J, Fromer M, Gauthier L, Goldstein J, Gupta N, Howrigan D, Kiezun A, Kurki MI, Moonshine AL, Natarajan P, Orozco L, Peloso GM, Poplin R, Rivas MA, Ruano-Rubio V, Rose SA, Ruderfer DM, Shakir K, Stenson PD, Stevens C, Thomas BP, Tiao G, Tusie-Luna MT, Weisburd B, Won HH, Yu D, Altshuler DM, Ardissino D, Boehnke M, Danesh J, Donnelly S, Elosua R, Florez JC, Gabriel SB, Getz G, Glatt SJ, Hultman CM, Kathiresan S, Laakso M, McCarroll S, McCarthy MI, McGovern D, McPherson R, Neale BM, Palotie A, Purcell SM, Saleheen D, Scharf JM, Sklar P, Sullivan PF, Tuomilehto J, Tsuang MT, Watkins HC, Wilson JG, Daly MJ, MacArthur DG (2016) Analysis of protein-coding genetic variation in 60,706 humans. Exome Aggreg Consort Nature 536:285-291 
19. Choi Y, Chan AP (2015) PROVEAN web server: a tool to predict the functional effect of amino acid substitutions and indels. Bioinformatics 31:2745-2747

20. Kumar P, Henikoff S, Ng PC (2009) Predicting the effects of coding non-synonymous variants on protein function using the SIFT algorithm. Nat Protoc 4:1073-1081

21. Adzhubei IA, Schmidt S, Peshkin L, Ramensky VE, Gerasimova A, Bork P, Kondrashov AS, Sunyaev SR (2010) A method and server for predicting damaging missense mutations. Nat Methods 7:248-249

22. Washington MT, Minko IG, Johnson RE, Wolfle WT, Harris TM, Lloyd RS, Prakash S, Prakash L (2004) Efficient and error-free replication past a minor-groove DNA adduct by the sequential action of human DNA polymerases iota and kappa. Mol Cell Biol 24:5687-5693

23. Stancel JN, McDaniel LD, Velasco S, Richardson J, Guo C, Friedberg EC (2009) Polk mutant mice have a spontaneous mutator phenotype. DNA Repair 8:1355-1362

24. Abrams ST, Lakum T, Lin K, Jones GM, Treweeke AT, Farahani M, Hughes M, Zuzel M, Slupsky JR (2007) B-cell receptor signaling in chronic lymphocytic leukemia cells is regulated by overexpressed active protein kinase CbetaII. Blood 109:1193-1201

25. Kataoka K, Nagata Y, Kitanaka A, Shiraishi Y, Shimamura T, Yasunaga J, Totoki Y, Chiba K, Sato-Otsubo A, Nagae G, Ishii R, Muto S, Kotani S, Watatani Y, Takeda J, Sanada M, Tanaka H, Suzuki H, Sato Y, Shiozawa Y, Yoshizato T, Yoshida K, Makishima H, Iwanaga M, Ma G, Nosaka K, Hishizawa M, Itonaga H, Imaizumi Y, Munakata W, Ogasawara H, Sato T, Sasai K, Muramoto K, Penova M, Kawaguchi T, Nakamura H, Hama N, Shide K, Kubuki Y, Hidaka T, Kameda T, Nakamaki T, Ishiyama K, Miyawaki S, Yoon SS, Tobinai K, Miyazaki Y, Takaori-Kondo A, Matsuda F, Takeuchi K, Nureki O, Aburatani H, Watanabe T, Shibata T, Matsuoka M, Miyano S, Shimoda K, Ogawa S (2015) Integrated molecular analysis of adult $\mathrm{T}$ cell leukemia/lymphoma. Nat Genet 47:1304-1315

26. Antal CE, Hudson AM, Kang E, Zanca C, Wirth C, Stephenson NL, Trotter EW, Gallegos LL, Miller CJ, Furnari FB, Hunter T, Brognard J, Newton AC (2015) Cancer-associated protein kinase $\mathrm{C}$ mutations reveal kinase's role as tumor suppressor. Cell 160:489-502

27. Mangino M, Hwang SJ, Spector TD, Hunt SC, Kimura M, Fitzpatrick AL, Christiansen L, Petersen I, Elbers CC, Harris T, Chen W, Srinivasan SR, Kark JD, Benetos A, El Shamieh S, Visvikis-Siest S, Christensen K, Berenson GS, Valdes AM, Viñuela A, Garcia M, Arnett DK, Broeckel U, Province MA, Pankow JS, Kammerer C, Liu Y, Nalls M, Tishkoff S, Thomas F, Ziv E, Psaty BM, Bis JC, Rotter JI, Taylor KD, Smith E, Schork NJ, Levy D, Aviv A (2012) Genome-wide meta-analysis points to CTC1 and ZNF676 as genes regulating telomere homeostasis in humans. Hum Mol Genet 21:5385-5394

28. Do SK, Yoo SS, Choi YY, Choi JE, Jeon HS, Lee WK, Lee SY, Lee J, Cha SI, Kim CH, Park JY (2015) Replication of the results of genome-wide and candidate gene association studies on telomere length in a Korean population. Korean J Intern Med 30:719-726

29. Du X, Rao MR, Chen XQ, Wu W, Mahalingam S, Balasundaram D (2006) The homologous putative GTPases Grn1p from fission yeast and the human GNL3L are required for growth and play a role in processing of nucleolar pre-rRNA. Mol Biol Cell 17:460-474

30. Zhu Q, Meng L, Hsu JK, Lin T, Teishima J, Tsai RY (2009) GNL3L stabilizes the TRF1 complex and promotes mitotic transition. J Cell Biol 185:827-839

31. Okamoto N, Yasukawa M, Nguyen C, Kasim V, Maida Y, Possemato R, Shibata T, Ligon KL, Fukami K, Hahn WC, Masutomi K (2011) Maintenance of tumor initiating cells of defined genetic composition by nucleostemin. Proc Natl Acad Sci USA 108:20388-20393

32. Thoompumkal IJ, Rehna K, Anbarasu K, Mahalingam S (2016) Leucine Zipper Down-regulated in Cancer-1 (LDOC1) interacts with Guanine nucleotide binding protein-like 3-like (GNL3L) to modulate Nuclear Factor-kappa B (NF- $\mathrm{BB})$ signaling during cell proliferation. Cell Cycle 15:3251-3267

33. Chen L, Johnson RC, Milgram SL (1998) P-CIP1, a novel protein that interacts with the cytosolic domain of peptidylglycine alphaamidating monooxygenase, is associated with endosomes. J Biol Chem 273:33524-33532

34. Rodriguez-Viciana P, Sabatier C, McCormick F (2004) Signaling specificity by Ras family GTPases is determined by the full spectrum of effectors they regulate. Mol Cell Biol 24:4943-4954

35. Lee CM, Yang P, Chen LC, Chen CC, Wu SC, Cheng HY, Chang YS (2011) A novel role of RASSF9 in maintaining epidermal homeostasis. PLoS ONE 6:e17867

36. Cohen-Salmon M, El-Amraoui A, Leibovici M, Petit C (1997) Otogelin: a glycoprotein specific to the acellular membranes of the inner ear. Proc Natl Acad Sci USA 94:14450-14455

37. Simmler MC, Cohen-Salmon M, El-Amraoui A, Guillaud L, Benichou JC, Petit C, Panthier JJ (2000) Targeted disruption of otog results in deafness and severe imbalance. Nat Genet 24:139-143

38. Schraders M, Ruiz-Palmero L, Kalay E, Oostrik J, del Castillo FJ, Sezgin O, Beynon AJ, Strom TM, Pennings RJ, Zazo Seco C, Oonk AM, Kunst HP, Domínguez-Ruiz M, García-Arumi AM, del Campo M, Villamar M, Hoefsloot LH, Moreno F, Admiraal RJ, del Castillo I, Kremer H (2012) Mutations of the gene encoding otogelin are a cause of autosomal-recessive nonsyndromic moderate hearing impairment. Am J Hum Genet 91:883-889 